\title{
The Role of Zakat Institutions in The Era Of The Covid-19 Outbreak: Philanthropy Movement Studies at The Kitabisa.Com Platform
}

\author{
Siswoyo Aris Munandar ${ }^{1)}$ \\ 1),Sekolah Tinggi Agama Islam Sadra, Jakarta, Indonesia \\ Corresponding author : siswoyoaris31@gmail.com
}

\begin{abstract}
:
The presence of the COVID-19 pandemic has brought changes to the world with various challenges that were never imagined before. In Indonesia, COVID-19 has infected more than 3.8 million people since the first case was announced in March 2020, however, efforts to slow the spread of the COVID-19 virus have hampered economic activity and its impact on the level of social welfare is increasingly felt by the community. As this research is very interesting, namely with the spirit of cooperation as a form of Pancasila and increased solidarity in society during the COVID-19 pandemic, philanthropy has a major role in complementing the presence of government programs. As done by the Kitabisa.com website, it has played a role in dealing with Covid-19 in Indonesia. This research is a research with qualitative method. The results of this research from its inception until 2019, during that time we can record that we have collected donations of up to IDR 502,375,254,938 from a total of 18,402 social campaigns and presented 1,352,169 digital philanthropists. In a short period and is expected to increase every year. On 27 June 2019, the Kitabisa.com platform has raised Rp700 billion in funds, since it was founded in 201. In the role of dealing with COVID-19, we can collaborate with various institutions, one of which is Gusdurian cares, and has the \#OrangBaik Movement, \#IndonesiaLawanCovid-19.
\end{abstract}

Keywords: Covid-19 Pandemic, Mutual Cooperation, Philanthropy, Kitabisa.com

\begin{abstract}
Abstrak:
Hadirnya pandemi COVID-19 telah membawa perubahan terhadap dunia dengan berbagai tantangan yang tidak pernah terbayangkan sebelumnya. Di Indonesia, COVID-19 telah menjangkiti lebih dari 3,8 juta orang sejak kasus pertama diumumkan pada bulan Maret 2020, namun, upaya untuk menghambat penyebaran virus COVID-19 telah menghambat kegiatan perekonomian dan dampaknya terhadap tingkat kesejahteraan sosial semakin dirasakan masyarakat. Sebagaimana penelitian ini sangat menarik yakni dengan semangat gotong-royong sebagai wujud Pancasila dan solidaritas yang meningkat di masyarakat pada masa pandemi COVID-19, filantropi memiliki peran besar dalam melengkapi kehadiran program pemerintah. Sebagaimana yang dilakukan oleh Website Kitabisa.com turut berperan dalam menghadapi Covid-19 di Indonesia. Penelitian ini adalah penelitian dengan metode kualitatif. Hasil penelitian ini Dari awal berdirinya sampai 2019, dalam kurun waktu tersebut kitabisa tercatat telah mengumpulkan dana donasi hingga Rp 502.375.254.938 dari total kampanye social sebanyak 18.402 serta menghadirkan 1.352.169 filantropis digital. Dalam kurun waktu yang singkat dan dipekirakan akan semakin meningkat setiap tahunnya. Pada 27 Juni 2019, Platform Kitabisa.com sudah mengumpulkan dana Rp700 miliar, sejak didirikan pada 201. Dalam peran menghadapi covid-19 kitabisa berkerjasama dari berbagai Lembaga salah satunya Gusdurian peduli, dan mempunyai Gerakan \#OrangBaik, \#IndonesiaLawanCovid-19.
\end{abstract}

Kata Kunci: Pademi Covid-19, Gotong-royong, Filantropi, Kitabisa.com 


\section{INTRODUCTION}

It's been more than a year since the COVID-19 pandemic has hit the world, especially in Indonesia. Of course, no one predicts that in 2020 the world will be hit by this disaster. In Indonesia, COVID-19 has infected more than 3.8 million people since the first case was announced in March 2020. The spread of the COVID-19 virus has hampered economic activity and its impact on the level of social welfare is increasingly felt by the community. After showing the achievement of poverty reduction in recent years, the poverty rate has increased again after the COVID-19 pandemic. In another fragment, people who tested positive and had to be quarantined were forced to just stay at home. While some of them do not have enough income, even if it is just to meet their daily needs. Such is the threat of increasing poverty rates due to the pandemic. ${ }^{1}$

However, there are still many Indonesian citizens who have the spirit of gotong royong which is the soul of the Indonesian people. ${ }^{2}$ especially during the COVID-19 pandemic. In 2018, Indonesia was named the most generous country in the world, according to a survey conducted by the British charity, Charities Aid Foundation (CAF). From the survey, Indonesia is ranked at the top with a score of 59. Developed countries are next in lines, such as Australia, New Zealand, America, and Ireland (Cindy Mutia, 2021).

As Pancasila contains values and beliefs that can be a guide in the life of the nation and state. As the nation's ideology, Pancasila values need to be instilled in every individual citizen from an early age. One of the important values implicit in the Pancasila ideology is the value of gotong royong (mutual cooperation). Assistant Deputy for Youth Empowerment, Coordinating Ministry for Human Development and Culture (Kemenko PMK), Yohan explained that the word gotong royong comes from a Javanese word. The word 'gotong' is paired with the word 'pikul or lift'. While the word 'royong' is paired with together. In simple terms, the word means lifting something together or it can also be interpreted as doing something together. ${ }^{3}$ Mutual cooperation and having an attitude of unity is one of the examples of life that has noble values from the third precepts of Pancasila which will lead to the direction of unity. Because this mutual cooperation is the rope that strengthens the Indonesian nation.

With the spirit of cooperation and solidarity increasing in the community during the COVID-19 pandemic, philanthropy has a major role in complementing the presence of government programs. As done by the Kitabisa.com website, it has played a role in dealing with Covid-19 in Indonesia. Kitabisa.com is an online crowdfunding platform that allows

\footnotetext{
${ }^{1}$ One in 10 people in Indonesia today live below the national poverty line. Child poverty rates can also increase significantly. The negative impact on the socio-economic situation of the pandemic could be much worse without any social assistance from the government. See, Mansur Efendi, "Management of Islamic Philanthropy in the Midst of the Covid-19 Pandemic: A Study on the Alms Courier Community", Philanthropy: Journal of Zakat and Waqf Management, Vol. 2 , No. 1, 2021, p. 5.

${ }^{2}$ As stated by Prof. Mohammad Nasroen (1907-1968), gotong-royong (Mutual Cooperation) has the characteristics of the Javanese language which means to lift (gotong) and together (royong). This later became the basis of Indonesian philosophy as reflected in the precepts of Pancasila. In the context of a pandemic, this philosophy becomes relevant when state actors, non-state actors and the public are required to work together to protect the surrounding environment and protect each other against the spread of the Covid-19 virus. In the context of Indonesia, of course, this premise can be justified, especially if we look back at the role of society, doctors, non-state actors (non-state actors) to state actors who worked hand in hand at the beginning of the darkness of the Covid-19 pandemic. at the same time other countries face their own challenges. Abhiram Singh Yadav, "Gotong Royong Against the Pandemic",https://national.kompas.com/read/2021/02/21/21114781/gotong-royong-melawanpandemi?page=all. (accessed August 17, 2021)

${ }^{3}$ https://www.kemenkopmk.go.id/mengurai-sepsi-gotong-royong-dalam-pancasila (accessed August 21, 2021).
} 
anyone to create social campaigns in the fields of education, medicine, humanity, natural disasters, charity, philanthropy, and so on (Windi Astuti, 2021). Because at times like this it is everyone's duty to work together to help each other and cooperation from various parties is needed. As a practical platform, Kitabisa.com facilitates crowdfunding activities, as evidenced by the data available on katadata.com, crowdfunding collected through Kitabisa.com has the highest number of donations compared to other donation collecting organizations.

If we look at the Kitabisa.com platform which has received a lot of positive responses from visitors to the Kitabisa.com website. The Kitabisa.com platform was launched or founded by Muhammad Al-Fatih Timur or often called Timmy, on June 6, 2013 (Nurul Fauziah, 2017). The movement of the Kitabisa.com platform is carried out using new media, especially social media as the main means. On social media, Kitabisa.com is present through Facebook, Twitter, and Instagram, Youtobe. Facebook, Twitter and YouTube. While chat applications are used such as Line and WhatsApp. Kitabisa.com also chooses online media and electronic media as outside branding tools (Syahrul Hidayanto, 2020). This platform has become a trusted platform for people in Indonesia to donate to social campaigns. It is proven by the achievements of Kitabisa.com since it was founded in 2013 until now it has facilitated more than 4,000 social campaigns and collected donations of more than 80 billion (Dian Andriani, 2017).

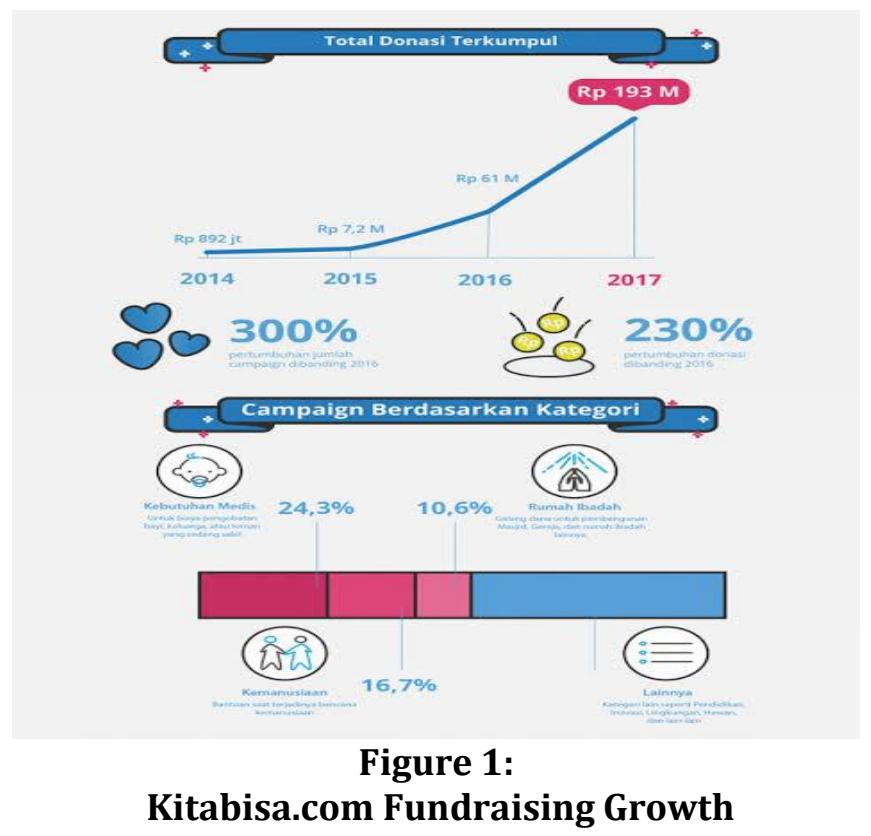

In 2017 Kitabisa.com launched a mobile application and in 2018 Kitabisa.com has connected 1 million \#OrangBaik and raised 500 billion in donations (Ferdiza Barthelemy, 2019). But that doesn't stop Kitabisa.com to stop innovating and trying to continue to grow, as evidenced in 2019 Kitabisa.com launched Kitabisa Plus, a program to help health among donors based on donations and presents a Routine Donation Program to make it easier for \#OrangBaik to donate regularly every month automatically (Rizka Novia, 2012). According to data from Giving Report0Kitabisa.com (2018), Kitabisa.com's crowdfunding has succeeded in raising funds of 490 billion rupiahs and has increased more than $100 \%$ from the previous year (Nanda Amalia, 2021). 


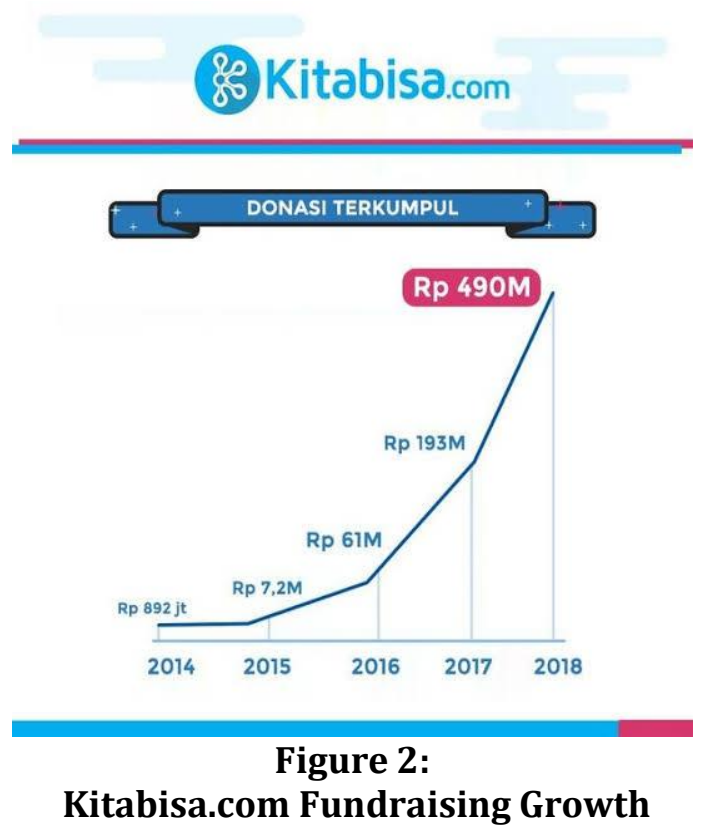

From its inception until 2019, during this period we can record that we have collected donations of up to IDR 502,375,254,938 from a total of 18,402 social campaigns and presented 1,352,169 digital philanthropists. In a short period of time and is expected to increase every year. On 27 June 2019, the Kitabisa.com platform has raised Rp700 billion in funds, since its founding in 2013. Judging from the Kitabisa.com website, in more detail, the donations collected to date, Saturday, 29 June 2019 amounted to Rp752.30 billion with 27,785 number of campaigns funded. Meanwhile, the number of 'good people' who joined the crowdfunding has reached more than 2.5 million people (Eva Rianti, 2021). As a social enterprise startup, Kita can charge an administration fee of $5 \%$ of the total donations in each campaign, except for natural disaster campaigns and zakat ( $0 \%$ administration fees). ${ }^{4}$ The campaign was created with an interesting caption, with a flow, and ended with an appropriate invitation to donate so as to attract the sympathy of the wider community and fellow users to do productive and charitable things through the philanthropic movement.

Therefore, the research is very interesting and the research focuses on the philanthropy and mutual cooperation movement carried out by kitabisa.com in the midst of the covid-19 outbreak. This research is very interesting because Indonesian citizens do not have to exalt Pancasila but Pancasila values are already embedded in their souls, and a question arises, "How is the Implementation of Pancasila in the Era of the Covid-19 outbreak carried out by Kitabisa.com?" To answer that, researchers surveyed on the platform, and followed Kitabisa.com social media during the COVID-19 pandemic. For the purposes of analyzing the Kitabisa.com Philanthropy Movement, researchers need a number of

${ }^{4}$ Kitabisa.com imposes an operational fee of $5 \%$ for Covid-19 fundraising as of July 1, 2021. This policy was adopted by adjusting Government Regulation No. 29 of 1980 in which one of the purposes of collecting money and goods is for health. In addition, Presidential Decree Number 12 of 2020 does not categorize the Covid-19 pandemic as a Natural Disaster. On this basis, Kitabisa.com as the organizer can charge a 5\% operational fee for the Covid-19 Fundraising. This change in operational costs for the Covid-19 Fundraising does not change the terms and conditions for creating the Fundraising page and the provisions for $0 \%$ operational costs for Natural Disaster Fundraising. See also Aulia Satrio Wibowo, "Differences in the Perceived Trustworthiness of Donating Students at Fundraisers Judging from the Type of Online Platform Used", Thesis, submitted to Semarang State University, 2020. 
supporting data, both from inside and outside, including: First, this primary data was taken from the Kitabisa.com crowdfunding, questionnaire. Second, secondary data is collected by reading, study the reports issued by Kitabisa.com, study the literature by reading text books, journals, lecture notes, papers, and other sources that the researcher deems necessary in this research. One of the purposes of this research is to show that Indonesian citizens still have the soul and are enthusiastic to work together to help others, especially in the Covid-19 era, where donations are made through the Kitabisa.com website.

\section{RESULTS AND DISCUSSION}

\section{A. Kitabisa.com Philanthropy Movement in the Covid-19 Era}

The magnitude of the impact of the pandemic on the economy is because many production and distribution activities are frozen due to Large-Scale Social Restrictions. The Ministry of Manpower noted that layoffs affected at least 3.05 million workers during the first three months of the pandemic. Not only in the formal sector, unemployment has also increased because many small entrepreneurs and informal workers cannot run their businesses during the PSBB. As a result, household consumption which has a share of $57.85 \%$ of gross domestic product (GDP) grew minus 5.51\%. During that time, donations and various forms of social assistance poured in. On the Kitabisa.com platform, for example, from Rp 168.4 billion collected to date, around Rp 150 billion in donations were received during the early days of the pandemic. There is hope that the economic recovery will occur in line with the loosening of social restrictions and the government's stimulus. However, many people still need a generous helping hand. Fundraising continues. Here are some fundraising sites that are often chosen by millennials when donating.

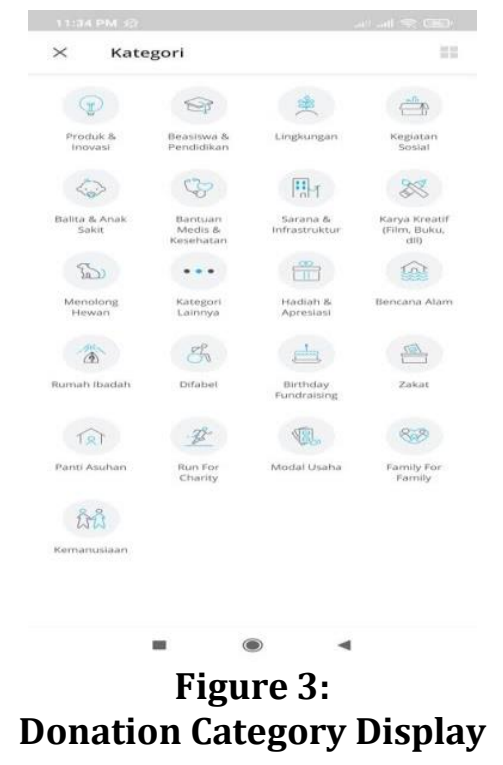

Kitabisa.com uses new media to disseminate information widely and on target, as well as to build relationships with the community. Kitabisa.com offers a new platform that is effective and efficient for the people of Indonesia, anyone can raise funds and anyone can donate. Now online donations have many advantages, one of which is not limited by space and time so that you can do social campaigns and donate anytime and anywhere. With easy and fast transactions, social campaign fundraisers and donors can save time and not spend a lot of energy (Muhammad Roby, 2020).

On April 14, 2020, the People's Consultative Assembly of the Republic of Indonesia (MPR RI) again initiated mutual cooperation efforts with various stakeholders as an effort to 
overcome the COVID-19 pandemic in Indonesia, we have launched various initiatives and programs, such as collecting partner aid funds through the Anak Bangsa Foundation. Can and 12 Driver Partner Welfare Programs at the end of March 2020, to support partners who serve the community safely in the midst of a pandemic. Solidarity and the spirit of national mutual cooperation, the MPR RI initiated the MPR Cares Against COVID-19 program by donating credit for online drivers, MSME merchants and other online service providers as one element of the affected community. Through the donation program "MPR RI Cares Against COVID$19 ", 5$, Gojek, and Kitabisa to raise funds for driver partners, MSME merchant partners, and other partners in the affected Gojek ecosystem. The collected funds will be distributed in the form of pulse vouchers to ease the burden of daily costs, considering that telecommunication services are one of the basic needs of Gojek partners when working.

MPR RI and BPIP with Telkomsel, Kitabisa, and Gojek ${ }^{6}$ ensure that assistance in the MPR RI Cares Against COVID-19 program will be distributed according to the needs of the beneficiary so that it can be right on target. On this occasion, the MPR RI also continues to invite other stakeholders to jointly protect Indonesia by working together to help the government and the Indonesian people in overcoming the COVID-19 pandemic. Kitabisa.com as a fundraising platform, supports all parties who want to do good, such as the movement initiated by the MPR RI and BPIP in collaboration with Telkomsel and Gojek in working together to help people affected by COVID-19. This initiation will certainly help the community, especially the informal workers through this crisis. This pandemic can be overcome with the support and cooperation of many parties.

On April 29, 2020, the Kitabisa crowdfunding startup noted, fundraising related to the corona pandemic reached Rp. 119.1 billion since mid-March 2020. These funds were obtained from 715 thousand donors. A lot of assistance was given in the form of masks to personal protective equipment (PPE) for medical personnel in early 2020 April. But getting here, there are many donations for basic necessities and they are in the form of food. In August 2020 the Kitabisa.com crowdfunding platform, donations related to the handling of Covid-19 reached Rp 168.4 billion. Of that amount, Rp 143.4 billion has been disbursed in stages. The number of donors who donated through the Kitabisa account was 852,954 people. Most of them are from the age group of 19-34 years. Meanwhile, community grant funds that enter the Task Force's account reach Rp. 159.84 billion. In addition, there was also a donation of Rp. 77.2 billion. The Task Force did distinguish between grants and donations recording. Grants are assistance in the form of funds submitted from the community to be managed by the Task Force. While donations are assistance given by the donor directly to the recipient. In handing over the donation, the Task Force only acts as a witness.

${ }^{5}$ Director of Human Capital Management Telkomsel Irfan A. Tachrir said, "Telkomsel understands that the need to continue to be connected is important, especially at a time when we need to keep our distance from each other to break the chain of the spread of COVID-19. Therefore, Telkomsel as a connectivity enabler seeks to connect the community by providing quality networks and easy access to telecommunications, including for those who are directly affected such as daily informal workers. Therefore, Telkomsel welcomes the collaboration with the MPR RI, BPIP, Kitabisa and Gojek in strengthening the attitude of mutual cooperation between lines. Hopefully this collective effort can help affected parties to be able to continue to face challenges in difficult times like now." Telkomsel customers can make donations through the UMB access menu *811\#, with a choice of denominations of 5,000 to 25,000 from prepaid deposits (pulsa) or postpaid billing for Telkomsel customers. In addition, the public can also donate through GoGive servicewhich is easily accessible by users on the Gojek application, which offers donation options starting from Rp. 1,000.

${ }^{6}$ Kitabisa, and distributed in the form of pulses to tens of thousands of partners in the Gojek ecosystem, such as driver partners, service provider partners, and MSME merchant partners in its ecosystem throughout Indonesia. 
On May 15, 2020 Kitabisa.com donations that have been collected for the handling of Covid-19 through its website reached IDR 130 billion. This amount was collected from various activities carried out by fundraisers on the site, the number of donors was quite diverse and varied. As the platform with the most users, Kitabisa.com is known as the top of mind in online donation sites (Asaretkha Adjane, 2020). There is Rachel Vennya, a celebgram, whose first day she posted on IG Stories, she was able to collect IDR 1.2 billion in one night. The corona virus in Indonesia does not only affect humans, but also animals. Many abandoned animals cannot get food, and animals in the zoo are not cared for because the zoo is empty of visitors. The condition of animals and animals is very concerning in the midst of a pandemic. Rachel Vennya to help animals affected by the corona virus collected more than Rp 600 million. The distribution of the first phase of assistance has also been carried out. At this stage, donations are distributed with the assistance of several institutions, including: First, distribution through the Wildlife Rescue Center Jogja, in the form of food and animal needs. Second, distribution of aid through the BOS Foundation in the form of providing food (vegetables and fruits), vitamins, and milk for 436 orangutans for 1 month. This assistance was given to Samboja Lestari (East Kalimantan) and Nyaru menteng (Central Kalimantan). Donations collected will continue to be distributed to animals affected by the corona virus. It is planned that the next distribution will be given to Medan Zoo, Bogor Mini Zoo Pamoyanan, and Bogor Deer Farm. ${ }^{7}$

Fundraising to help deal with COVID-19 in Indonesia through the website Kitabisa.com, has been able to collect as much as Rp. 130 billion. Founder and CEOKitabisa.comAl Fatih Timur said that the mutual fundraising has been carried out by various groups including artists and influencers and even children. As forkitabisa.comis a fundraising site or "online charity box" that anyone can start. Through this page, the community can donate some of their fortune to help others with the concept of gotong royong (Mutual cooperation) (National Task Force Public Communication Team, 2021).

As did Atta Halilintar, Raffi Ahmad, and of course not only artists, there is a community. Indonesian people still have a high spirit of solidarity and community cooperation in dealing with the Covid-19 pandemic. However, one of the donors who impressed Alfatih the most was a 6th grader. He then showed a video of the child's testimony, Rifdah Rahmah. In the video, Rifdah admitted that she had never donated on the Kitabisa.com site before. Rifdah then saw the fundraising activities of the celebgram Rachel Vennya and a number of other influencers. One day, after returning from her grandmother's house, Rifdah immediately decided to donate the money she had just received amounting to Rp. 15,000. The donation was given to help medical personnel carry out their duties. ${ }^{8}$

${ }^{7}$ To help animals affected by the corona virus, Rachel Vennya together with BOSF (Borneo Orangutan Survival Foundation) raised funds to save the animals. Tens of thousands of \#OrangBaik work together to help animals affected by the corona virus through donations to the Rachel Vennya fundraiser. The donations collected are used to feed, care for the animals, provide PPE facilities for the veterinarians, baby sitters, and technicians involved.https://lawancorona.kitabisa.com/post/rachelvennya-galang-dana-for-an-terdampak-corona, (accessed August 10, 2021).

${ }^{8}$ Rifdah saw a lot of medical personnel who still need a lot of PPE, need funds too, so what should we help other than stay at home. Because of that Rifdah has not been able to donate enough, Rifdah tries to make a modest donation so that she can help medical personnel too. While shedding tears, Rifdah hopes that medical personnel will always be healthy and that this epidemic will end soon. According to Kitabisa.com, what Rifdah did was to teach the public that donations are not measured by the amount given, but the sincerity of the giver, read Devina Halim's article,https://national.kompas.com/read/2020/05/15/16321651/donasi-handling-covid-19-dari-

kitabisacom-reach-rp-130-miliar?page=all, (accessed August 11, 2021). In that story, Rifdah Rahmah at the same time opens the mind to everyone that giving charity does not have to wait for us to have money, it is not measured by the nominal, but the most important thing is sincerity and sincerity. In 


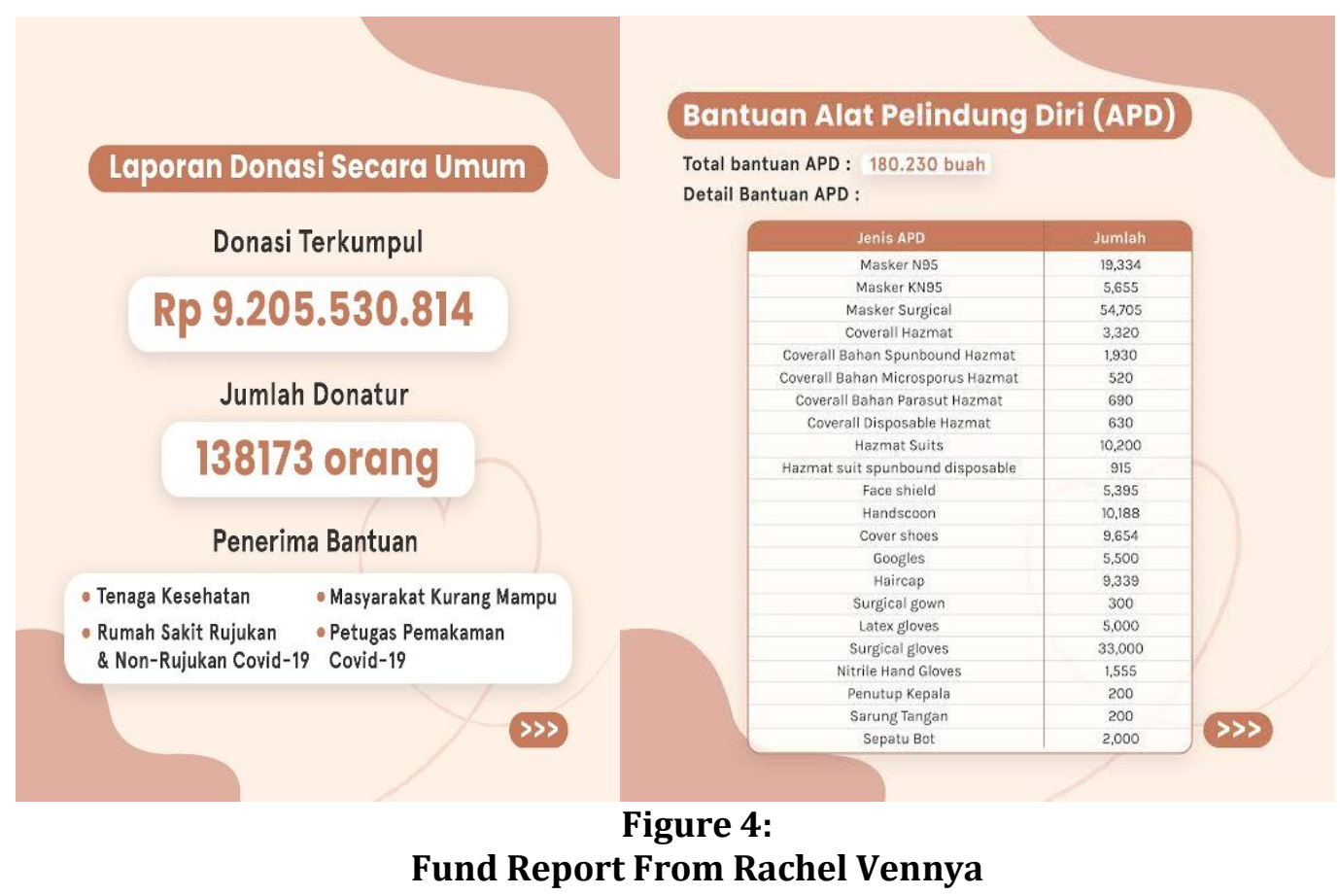

Seeing the condition of Indonesia in the midst of the current outbreak of the Covid-19 virus, medical personnel and volunteers are struggling to overcome the increasingly widespread spread. Those we call medical heroes give time \& energy to heal patients even though many medical professionals are studying because of contracting the Covid-19 virus. Seeing all this, the Indonesian people who have more assets, many are moved to help people in need by making donations which will be distributed in the form of masks, hand sanitizers, disinfectants and other personal protective equipment (PPE) that they really need. This donation is also to help the poor who need Covid-19 prevention tools that they cannot get at this time, such as masks, hand sanitizers, and disinfectants.

The Covid-19 pandemic has forced a lot of business to be hampered. Several efforts have been made to fight this pandemic, one of which is by raising donations. Meanwhile, the volunteers sincerely went down to the community to carry out social actions as JD.id collaborated with Kitabisa.com to hold an action against corona to help medical personnel, frontline volunteers and people in need through \#IndonesiaLawanCorona, \#KarenaSehatNo1 \#DonasiPeduliCovid- 19.

One of them, influencer Rachel Venya, was able to collect donations of IDR 9.1 billion. Then, music observer Adib Hidayat Rp 1.9 billion and musician Afgan Syahreza Rp 214 million. Now, Kitabisa is collaborating with Gojek through the Anak Bangsa Bisa Foundation (YABB) and the music group Slank to raise funds. This donation is targeted to reach $\mathrm{Rp} 15$ billion. The funds collected will be used to help freelancers such as hawkers, angkot or city transportation drivers to online motorcycle taxi drivers affected by the corona pandemic. On

this time of pandemic, there are many things that everyone can do to help others. Not only donating through online media, but you can also provide assistance to the closest people directly. In addition, the community can help each other break the chain of the spread of COVID-19 by staying at home following the health protocol rules from the government. See the Public Communications Team of the National Task Force, https://covid19.go.id/p/berita/ceo-kitabisacom-dana-rp-130-miliar-terkumpuluntuk-bantu-sesama-selama-pandemi-covid-19 
a different occasion, Kitabisa.com Co-Founder Vikra Ijas said, during the pandemic, many institutions were collecting donations. The various donations collected reinforce the notion of the high level of generosity of the Indonesian people. There are at least three categories for collecting corona donations. First, help medical personnel. Second, the distribution of food through public kitchens. Third, basic necessities for underprivileged residents who have been affected by the corona pandemic. Donations with the keyword corona also become the main topic on social media (Cindy Mutia, 2021).

The JD Peduli \#IndonesiaLawanCorona program itself has been started since April 8, 2020, and is planned to end in mid-June 2020. The plan is to use this donation to help provide PPE (Personal Protective Equipment), masks, and antiseptic liquid for those in need, as well as spraying. disinfectant liquid for free, in several red zones in the Greater Jakarta area. Later all donations that have been collected will be handed over directly to several government Referral Hospitals, through Kitabisa.com. This is because the number of patients infected with COVID-19 in Indonesia is quite high and the spread of the virus is also fast, it is impossible for the government to act alone in dealing with this disease outbreak (merdeka.com, 2021).

As of April 12, 2020, the \#BersamaLawanCorona crowdfunding campaign has managed to raise 101 billion funds from more than 3,300 campaigns. This achievement will be difficult to implement without the help of digital technology and the internet. Digital technology and the internet allow information to spread more quickly and widely without time constraints, thus opening up opportunities for more people to participate in the \#BersamaLawanCorona crowdfunding campaign. The availability of various ways of accessing information on the Kitabisa platform, such as through the desktop and mobile versions of the website, as well as mobile applications for iOS and Android, makes it easier for the public to get information about the crowdfunding campaign. People can easily access information about the progress of the funds raised, the deadline for the implementation of the campaign, background stories and fundraising objectives, the latest information from fundraising regarding fund development and funding provision, who are the donors, how much each donation is donated, when to donate, and comments from donors (Dhyayi Warapsari, 2020).

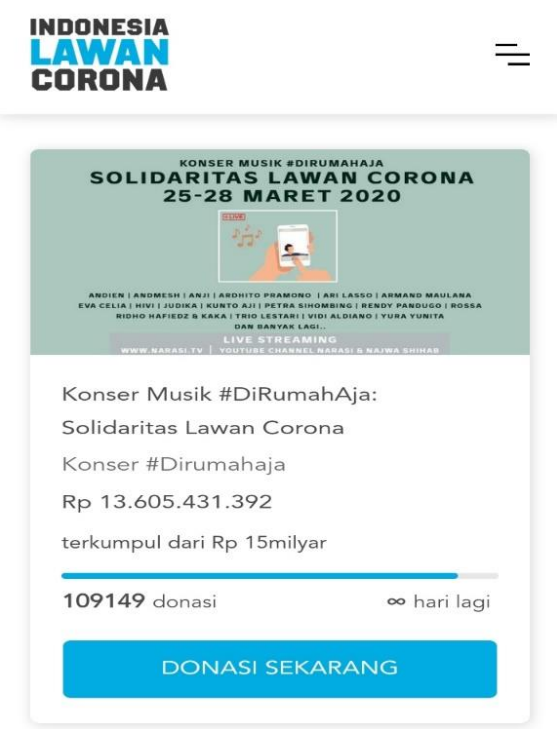

Figure 5: 


\section{Donate in Solidarity Against Corona ${ }^{9}$}

In coordination with various partners and institutions, Kitabisa currently continues to channel public donations for various needs related to the \#BersamaLawanCorona effort, such as tools for health workers, test kits to hospitals, as well as food assistance and safety kits for vulnerable communities. To jointly face COVID-19, collaboration from many parties is needed, including in raising public funds and distributing aid to those in need. Thousands of people have been and will continue to work together against COVID-19. Pluang10in collaboration with Kitabisa.com managed to raise funds of Rp. 30,434,557 in the month of Ramadan 1442 Hijriyah. The fundraising fund was allocated to purchase new clothes, stationery, food, toys, and other necessities for orphans celebrating Eid al-Fitr. The distribution of aid was marked by placing happiness boxes at two orphanages, namely Griya Yatim Dhuafa, Kayu Manis Dormitory, Matraman in East Jakarta and Griya Yatim Dhuafa, Kranggan, Bekasi, for the period from May 8 to May 12, 2021. In this campaign, Pluang CoFounder Claudia Kolonas said, Pluang invites investors to invest while giving charity during the last holy month. The mechanism is that investors can donate automatically worth Rp. 20 . 000 to orphans for every gold purchase of at least 1 gram through the GoInvestation feature in the Gojek application. Then, he said, all the funds collected were included in the Kitabisa.com-supported Happiness Box program. Claudia Kolonas admitted that she was satisfied with this positive collaboration. This collaboration is a good way for investors to still care about each other in the midst of their struggle to achieve their financial goals.

This campaign resulted in a positive response, where investors could simultaneously invest and donate. Claudia added, Pluang will continue to look for ways to help people in need while increasing the number of investors in Indonesia. As an investment application, Pluang still has to support government programs to increase the level of financial inclusion. The Head of Corporate Affairs GoPay Winny Triswandhani also conveyed the same thing. According to him, GoPay is always committed to making it easier for people to help others, including this sharing while investing initiative (kitabisa.com, 2021).

\section{B. Kitabisa.com and the \#OrangBaik Movement}

Kitabisa.com is an online platform and technology for individuals, communities, organizations and companies who want to raise funds by creating an online donation page. Those who have collaborated with RSCM since the beginning of 2019 whose donation targets are all patients who do not have health insurance. Some examples of cases from Kitabisa.com Crowdfunding: First, Digital Disaster and Mutual Cooperation-Lombok Earthquake: 22 Billion Rupiah collected from 80,000 \#orangbaik (as donors of funds) who donated through 447 online fundraisers created. Second, Medical Fundraising, 7,500 medical category fundraisers made on kitabisa.com and collected donations of Rp. 34,163,928,466. Third, the Online Joint Venture on National Issues and Malnutrition in Asmat, through kitabisa.com, has collected 1.7 billion from 40 online fundraisers (Tim Kementrian Kesehatan RI, 2019).

The \#orangbaik Philanthropy Movement was also carried out by the artist, Dimas Beck, who was moved to help people who are struggling during the corona outbreak. He saw the struggle of health workers who are at the forefront to fight COVID-19, as well as people

\footnotetext{
${ }^{9}$ Kitabisa raise funds with the nature of crowdfunding (raising funds to be donated or donated), the campaign period is 480 days, and it lists the number of people who have been successfully invited to donate (link) for donors. See Driana Intyaswati, "Messages of Communication in Fundraising Through Websites", Journal of Information Studies of Communication Studies, Vol. 46. No. 1, 2016, p. 85.

${ }^{10}$ Pluang is a multi-asset investment application consisting of digital gold, crypto assets, Micro EMini S\&P 500, and mutual funds. Recently, Pluang collaborated with UOB Asset Management Indonesia as the investment manager of the mutual fund, offering two mutual funds, the UOBAM Dana Rupiah money market mutual fund and a fixed income fund under the name UOBAM Dana Pembangunan Negeri.
} 
whose economy has been affected by the corona so that it is difficult to meet their daily needs. Through his fundraising campaign at Kitabisa, Dimas Beck wants to provide food assistance for medical personnel and people in need. He hopes that the assistance provided can ease the burden of those who are experiencing difficulties in the midst of the pandemic.

Gradually, assistance from the \#OrangBaik at the Dimas Beck fundraiser has been distributed. During the distribution period from May 19 to June 13, 2020, food packages from Laukita have been given to those in need. The assistance was distributed with the help of Baznas. In addition to raising funds for Dimas Beck, this assistance was also collected from the Melly Goeslaw campaign, and Warteg gratis. A total of 4378 portions of food have been distributed. The aid was distributed to several points, ranging from hospitals, Islamic boarding schools, foundations, places of worship, shelters for online motorcycle taxi drivers, to homes for underprivileged residents in the Jabodetabek area (lawancorona.kitabisa.com, 2021).

Donations from \#OrangBaik at Doctor Tirta's fundraiser have been distributed. In total, more than 199,000 PPE have been provided to 340 health facilities (hospitals and health centers). Hundreds of hospitals and health centers that have received assistance are scattered throughout Indonesia. Not only that, Doctor Tirta also distributed aid to help build a Field Hospital and other assistance for those affected by the pandemic. The struggle of the Indonesian people has not yet ended, as well as the kindness that the \#Baik People have given. Solidarity to help others in need in the midst of a pandemic continues to spread and spread. We are working together to help each other fight corona. In the midst of a situation like this, everyone is struggling together, starting from the health workers and the community who help each other.

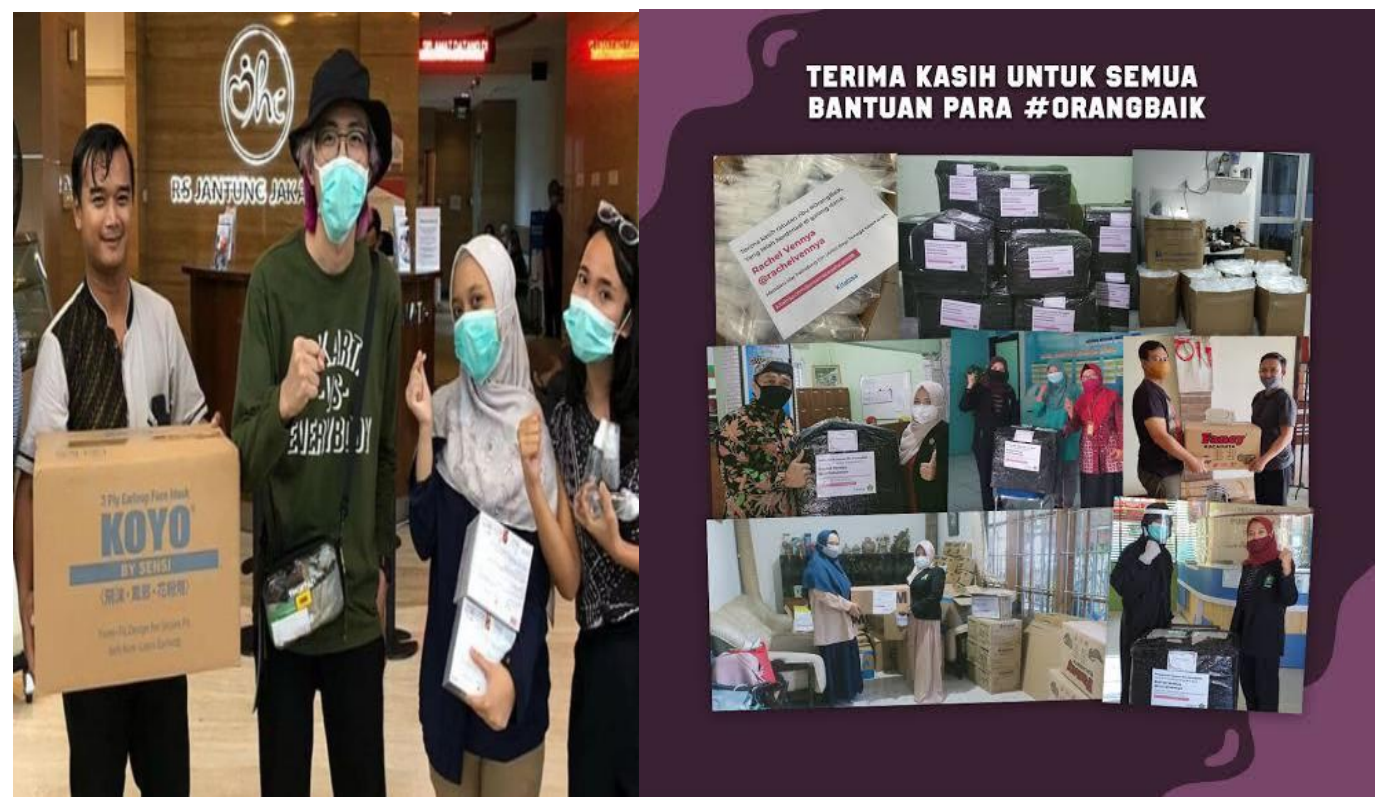

Figure 6:

\#OrangBaik Fund Distribution

Doctor Tirta's fundraiser, kitabisa.com/bersatusalingbantu, managed to collect more than Rp 5 billion in donations. A total of 24,822 \#OrangBaik helped by donating. This is a testament to the magnitude of our solidarity together. As a \#Kindness Courier, Dr. Tirta is honored to be able to deliver \#GoodPeople's care to those in need. He is also proud of the 
community's spirit of mutual cooperation that helps each other for others in need (lawancorona.kitabisa.com, 2021).

When we read the media INAnews.co.id, On May 29, 2021 Still in the framework of National Elderly Day and to support the government's program to accelerate the distribution of the COVID-19 vaccine, PT ASURANSI JIWA ASTRA (Astra Life) collaborated with kitabisa.com to hold a fundraising event. will be donated to provide accommodation for the COVID-19 vaccine and post-vaccination packages in the form of basic necessities and vitamins for poor elderly people in the Jabodetabek area. The collected funds were multiplied by Astra Life during Hardolnas (National Online Donation Day) on 7 May 2021. As a result of this activity a total of Rp. 330 million from 7,885 \#orangbaik or donors through the kitabisa.com application.

The government's COVID-19 vaccine delivery program which has focused on the elderly since early 2021 is still running until now, where even though the vaccine is given free of charge, there are still many elderly people who have not been able to access the vaccine due to mobility constraints to the vaccine center and the lack of companions. Windawati Tjahjadi as President Director of Astra Life said, "Astra Life is committed to always being there for the community, especially in difficult conditions like today. We believe, this pandemic condition can be passed if we work hand in hand together to support the government's program for vaccine distribution so that the Indonesian people can quickly recover from the pandemic. We hope that with this program, we will also accelerate the vaccination program, especially for the elderly group who is vulnerable to the risk of COVID-19 transmission." (lawancorona.kitabisa.com, 2021).

In its implementation, Astra Life also collaborates with the Community of Fight Libas Covid-19 (KILLCOVID19) which is a community that has a vision to stop the spread of COVID19 in Indonesia, which is chaired by Adharta Ongko Saputra, a survivor of COVID-19. This program is targeted to be able to accommodate more than 600 elderly people in the Greater Jakarta area to get vaccines where the first batch will begin on June 9, 2021 at St. Hospital. Elisabeth, Bekasi. Registered elderly poor people will be provided with a shuttle service from their residence to the partner vaccine center, of course, while still implementing health protocols. After receiving the vaccine, participants will receive a post-vaccine package in the form of basic necessities and vitamins. This program is part of a series of health campaigns initiated by Astra Life since early 2021 and is in line with the focus of the Astra Group's health care program. Astra Life is always there and continues to support the community to be able to live a healthy life and love life. Healthy Affairs, No Worries \#iGotYourBack (Andre Rama, 2021).

A number of artists are vying to step in to help people with Covid-19. Recently, Singer Andien Aisyah was moved to raise funds for Covid-19 patients, which is specifically for patients with low incomes. Andien's fundraising was collected through the kitabisa.com page. This was known through the official Instagram upload of @andienaisyah. On Sunday, July 11, 2021, the collected donations amounted to Rp. 42 million from the target of Rp. 50 million. The donations came from 289 donors. Andien feels sad to see the increasing number of Covid-19 cases in Indonesia because the number of Covid-19 cases has reached more than 2 million with a daily number of 20,000 cases. In fact, many health facilities can no longer accept patients. We are already experiencing an emergency, even more worrying than the initial conditions of the pandemic in 2020. Therefore, He invited the public to donate to help Covid-19 patients. Including, for health workers, volunteers, and economically weak residents affected by Covid-19. By working together, immediately donate to help hospitals, health centers, health workers, volunteers, and economically weak residents affected by the pandemic (wiwi, 2021). 


\section{Kitabisa.com in collaboration with Danone Indonesia: \#Introduction to Kindness Movement}

On 18 January-5 February 2021 Danone Indonesia is one of the largest food and beverage companies in the world whose mission is to provide health to as many people as possible. Danone operates in 130 countries with more than 100,000 employees worldwide ${ }^{11}$, which collaborated with Kitabisa.com by providing 1,000 food packages to families in need in Bandung, Bekasi, Bogor and Sukabumi. The package consists of food and bottled drinking water to help meet daily nutritional and hydration needs to stay healthy in the midst of this pandemic. In addition, the officers who deliver these basic food packages (also known as \#KurirKebaikan) are non-formal workers appointed by Kitabisa.com. The senders and recipients of this assistance are intended for those with uncertain incomes such as daily workers, online motorcycle taxi drivers, to street vendors. This is done in order to support the fulfillment of daily food needs for them and their family members (Mia Chitra Dinisari, 2021), Through the \#PengantarKebaikan program carried out by \#KurirKebaikan, it is hoped that it can ease the burden of daily workers so that they can both survive in the midst of these uncertain conditions.

This activity is part of Danone Indonesia's commitment to provide assistance worth Rp. 30 billion in efforts to contain and prevent COVID-19 in Indonesia. So that through this program, it is not only beneficial for those who receive donations but can also help empower people who have lost their jobs so that they can get their income back. In addition, each courier is also provided with hand sanitizer and gloves so that the process of distributing food items can still follow strict health protocols. The distribution process carried out through \#KurirKebaikan is an effort to comply with the Implementation of Community Activity Restrictions (PPKM) in accordance with government policies, so as to avoid crowds and still maintain physical distance.

Marisa Thara Wardhani, Head of Brand Partnership Kitabisa.com said, "We welcome collaboration with Danone Indonesia to contribute to helping others in need and affected by this pandemic. Through the \#PengantarKebaikan program carried out by \#KurirKebaikan, it is hoped that it can ease the burden on daily workers so that they can both survive in the midst of these uncertain conditions." During the COVID-19 pandemic, Danone in Indonesia has collaborated with the government, various institutions, hospitals, and social organizations to distribute assistance in the form of personal protective equipment, medical equipment such as ventilators and beds, nutrition and hydration assistance for medical personnel, to groups susceptible. Furthermore, Danone Indonesia will continue to provide assistance and cooperate with various parties so that they can contribute and mobilize the community to take care of each other to overcome the impact of COVID-19 in Indonesia (pressrelease.kontan.co.id, 2021).

\section{Kitabisa.com Collaborating with KompasTv and Tribunnews in Handling Covid-19.}

Tribunnews.com plays a role in preventing the spread of the corona virus or Covid19, the community fundraising platform (crowd funding) kitabisa.com andTribunnews.com, take part in preventing the spread of the corona virus or Covid-19 by distributing donations of medicine and donations supplement to several social institutions in DKI Jakarta. Various types of medicine for mild to moderate pain supplement, donated to three social institutions

\footnotetext{
11In Indonesia, Danone's business consists of two product categories that focus on public health at every stage of life, namely, Danone Waters which produces Bottled Drinking Water \& NonCarbonated Drinks with its products such as AQUA, Mizone, VIT, VIT Levite and Danone Specialized Nutrition with their products. such as SGM Eksplor, SGM Bunda, Lactamil, Bebelac, Nutrilon Royal and medical nutrition. The Danone Group in Indonesia has 23 factories with more than 15,000 employees
} 
located in the Cipayung area, East Jakarta. medicine and supplement Socially assisted residents are very much needed because they are generally elderly and experience physical and psychological disorders, making them vulnerable to contracting Covid-19.

The three social institutions that were donated by Tribunnews.com and kitabisa.com are the Bina Laras Harapan Sentosa 2 Social Institution, the Bina Insan Bangun Daya 2 Social Institution, and the Tresna Werdha Budi Mulia 1 Social Home, all of which are located on Jln Bina Marga, Cipayung, East Jakarta. medicine and supplement Socially assisted residents are very much needed because they are generally elderly and experience physical and psychological disorders, making them vulnerable to contracting Covid-19. There are more than 560 fostered residents at the Bangun Daya Insan Panti, around 230 assisted residents are people with social problems in the total care category. As is known, at the Bangun Daya 2 Panti Bina Insan, it becomes a kind of gate for the shelter for People with Social Welfare Problems (PMKS) brought by the DKI Jakarta Social Service (Sanusi, 2021).

Apart from that, various community efforts to help those affected by the pandemic continue. Not only showing compassion, there is creativity to the use of technology in these various activities. For example the late Didi Kempot. The singer of campursari songs held a charity concert from his home on April 11, 2020. The three-hour concert which was broadcast on KompasTV managed to collect Rp 7.6 billion for the handling of Covid-19. Chief Editor of Kompas TV news channel Rosiana Silalahi stated that Didi Kempot ${ }^{12}$ never discussed the honorarium for the concert.

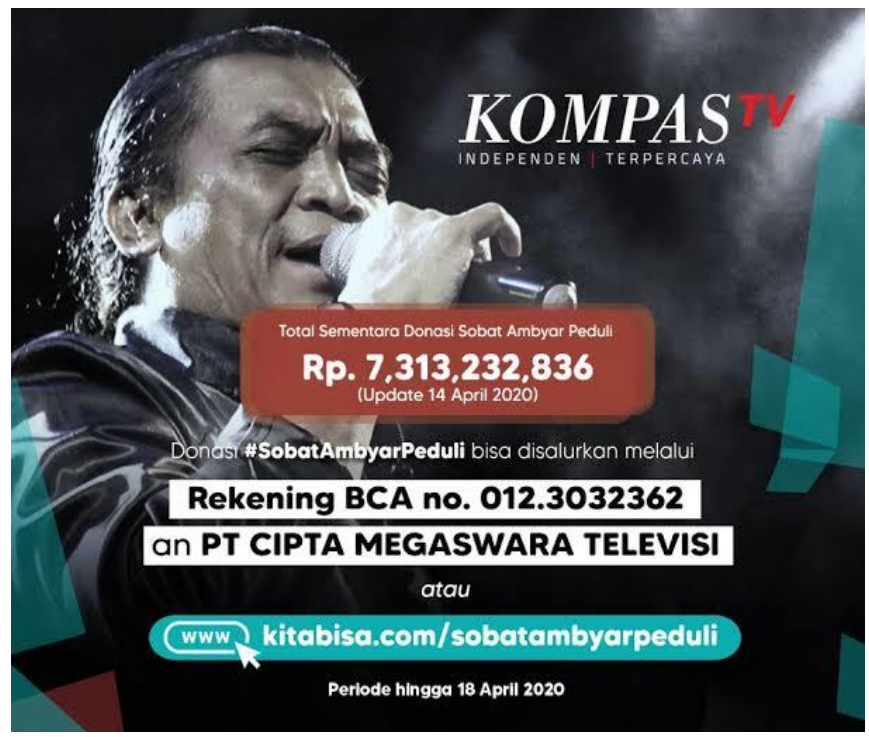

Figure 7:

Charity Concert in Helping Handling Covid-19.

Then there was Armand Maulana who auctioned off his personal belongings for donations. Likewise, fundraising through virtual concerts is mostly done by Indonesian artists, from Rhoma Irama, Giring Nidji, Andien, to Bimbo. But it's not just the materials needed to deal with the current pagebluk. There is a lot of social work that can be done to help the community in dealing with the outbreak. Then there's Anne Avantie. In the midst of the pandemic, the designer of the bridal kebaya also produces masks and personal protective jackets. His masks are made from the wastra of the archipelago, so he can help traditional cloth craftsmen in various regions to keep working. As for the personal protective jacket, Anne uses a material that can protect the user from droplets. Match with the mask, The jacket

12 The Lord of Broken Heart died in Solo on May 5, 2020. 
uses wastra fabric accents to make it look more fashionable. Anne, a woman from Semarang, sells masks at a price of Rp. 200-500 thousand, while her jackets are Rp. 350 thousand to 1.25 million. As much as $20 \%$ of the sales proceeds are channeled as donations through the Wisma Kasih Bunda Foundation.

\section{E. Gusdurian Peduli and Kitabisa Solidarity in the Middle of Covid-19}

GUSDURian Peduli is an institution specially formed by the Indonesian Gusdurian Network, to manage the work of the Indonesian Gusdurian Network in the fields of Disaster Response, Social and Economic Empowerment and Organizing Disaster Response Volunteers, previously named 'Gusdurian Amal Barn'. Since the establishment of the Gusdurian Amal Barn in 2014, the Indonesian Gusdurian Network has been heavily involved in the work of handling victims of natural disasters and social disasters in various regions in Indonesia, starting from providing scholarships for underprivileged children since 2014 until today, assistance for Rohingya refugees in Aceh (2015), assistance for the tragedy of the murder of Salim Kancil in Lumajang (2015), assistance for victims of the suicide bombing in Surabaya (2018), to victims of the earthquake in Lombok and victims of the Tsunami Earthquake in Palu, Sigi and Donggala (2018). Departing from the experience of dealing with disaster victims in various regions, it was then deemed important to create an institution that specifically handles Gusdurian's work in the humanitarian field.

In the era of the Covid-19 outbreak, The GusDurian network launched the \#salingjaga program by cooperating with or collaborating with the Islamic Love Movement led by Haidar Bagir. The \#mutualguarding against Corona movement is a joint movement to help the economic needs of informal sector workers who are vulnerable to being affected by the Corona virus, including small communities. The \#SalingJaga Gusduri movement helps or provides basic and daily needs such as; hand sanitizer, masks, gloves, and personal protective equipment for doctors. The beneficiaries are poor people in big cities, laborers, and informal sector workers. This movement is in kitabisa.com, Benih Baik, Media Group, Islamic Movement of Love and PeaceGen. The \#SalingJaga movement is one of several fundraising and aid distribution programs carried out by Gusdurian Peduli. There is still a lot of Gusdurian Peduli's fieldwork to distribute aid packages from various organizations, institutions, and companies. Such as distribution of 1,000 food packages from iForte; 50,000 masks from Gajah Tunggal Group; 3,500 food packages and cleaning supplies from Grab, OVO, and Tokopedia; Personal Protective Equipment (PPE) from Media Group for medical personnel; 4,000 food packages and clean-and-health packages from Sido Muncul; and much more. ${ }^{13}$

${ }^{13}$ Looking at the Kitabisa.com platform, the assistance has 37,494 donors, the \#SalingJaga Movement has collected donations of 5.8 billion rupiah. The donations were then changed or bought for basic food packages, clean-health packages, and information (educational) packages through 68 posko with around 900 volunteers, while Gusdurian Peduli and the Islamic Love Movement have 33 posko spread across many cities in Indonesia and there is one city in Indonesia. Malaysia. See, Siswoyo Aris Munandar, "The Gusdurian Network Philanthropy Movement in the Middle of the Covid-19 Outbreak", Journal of Islamic Guidance, Vol. 14, No. 1, 2021, p. 55. 


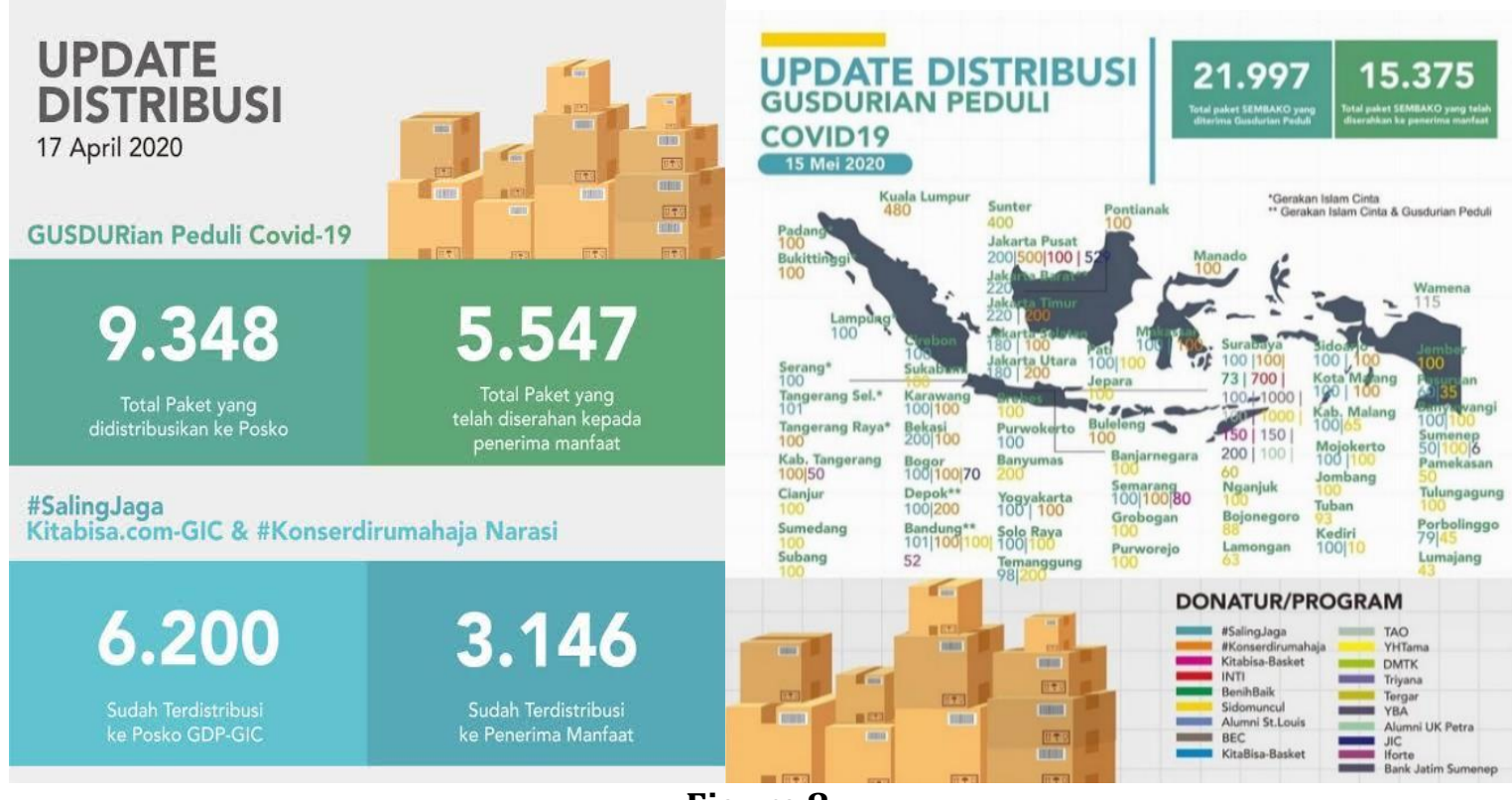

Figure 8:

Update on the distribution of Gusdurian Peduli and Kitabisa.com

GUSDURian Peduli as one of the working wings of the GUSDURian Indonesia Network has established 67 GUSDURian Peduli Covid-19 Command Posts in 67 seven cities in Indonesia and Malaysia. These posts were established to help the most vulnerable residents affected by the pandemic, namely informal sector workers who depend on their income from daily salaries, such as angkot drivers, online motorcycle taxi drivers, traveling traders, tourism workers, and so on. Until now there are at least more than 1000 volunteers who are members of this movement. The GUSDURian Peduli Working Team is led directly by the National Coordinator of the GUSDURian Network, Alissa Wahid. In collaboration with the Islamic Love Movement and kitabisa.com, GUSDURian Peduli is building the \#SalingJaga movement.

This fundraiser was also fully supported by the social figures of Narasi TV who organized the \#DiRumahAja music concert entrusting the distribution of the funds they got to GUSDURian Peduli of around 2 billion rupiah. The donation was then allocated to purchase food packages, masks, soap, and hand sanitizers which were distributed to families in need. As of May12, 2020 GUSDURian Peduli has distributed more than 14,000 basic food packages and clean and healthy packages to residents in 67 regions (covid19.go.id, 2021).

The impact of Covid-19 for Education must implement an online system, when the new school year begins by implementing a learning system from home, many students have difficulty following lessons because they do not have supporting facilities, namely cellphones. For families who can't afford it, buying a cellphone feels very burdensome on their finances, not to mention the cost of buying an internet data package, it feels even more burdensome for their parents. There have been many stories of how many underprivileged children have to fight with relatives or borrow friends to force their parents into debt to study. Currently, some of our people are moved by supporting students who do not have cellphones. Inviting people both to donate new and used cellphones, or temporarily lend their cellphones until the student's family can afford to buy their own, as GUSDURian Peduli has done in many areas: Surabaya, Karawang, Malang, Gorontalo, and other areas. However, this movement still needs our helping hand considering the number of our brothers and sisters in need.

Through the Smarttree for Students Movement for this, we invite good people to set aside their sustenance by donating to this program. Your donation will be channeled to help 
our brothers and sisters who do not have mobile phones to be happy to participate in school learning activities from home. The distribution of donations will be carried out by local community networks coordinated by GUSDURian Peduli friends.

\section{CONCLUSION}

The COVID-19 pandemic not only has an impact on public health, but also affects the economic conditions, education, and social life of the Indonesian people. The presence of the COVID-19 pandemic has brought changes to the world with various challenges that were never imagined before. With the spirit of mutual cooperation and solidarity increasing in the community during the COVID-19 pandemic, philanthropy has a major role in complementing the presence of government programs. As done by Website Kitabisa.com has a role in dealing with Covid-19 in Indonesia, Kitabisa.com has a communication strategy through the use of social media. The strategy is to upload content that contains storytelling and video formats in each campaign that will be carried out on the social media used. With video formats, The recording can be played repeatedly so that it attracts the attention of people who want to donate to the social campaign compared to the photo format. The social media campaigns conducted by Kitabisa.com have so far reached many audiences who share the same interests as Kitabisa.com's goals.

From its inception until 2019, during this period we can record that we have collected donations of up to IDR 502,375,254,938 from a total of 18,402 social campaigns and presented 1,352,169 digital philanthropists. On April 29, 2020, the Kitabisa crowdfunding startup noted, fundraising related to the corona pandemic reached Rp. 119.1 billion since mid-March 2020. These funds were obtained from 715 thousand donors. A lot of assistance was given in the form of masks to personal protective equipment (PPE) for medical personnel in early 2020 April. But getting here, there are many donations for basic necessities and they are in the form of food. In August 2020 the Kitabisa.com crowdfunding platform, donations related to the handling of Covid-19 reached Rp 168.4 billion. Of that amount, Rp 143.4 billion has been disbursed in stages. The number of donors who donated through the Kitabisa account was 852,954 people. Most of them are from the age group of 19-34 years. Meanwhile, community grant funds that enter the Task Force's account reach Rp. 159.84 billion. In addition, there was also a donation of Rp. 77.2 billion. And the Kita Philanthropy Movement can collaborate with various institutions such as KompasTV, Trimbunnews, Gusdurian Peduli, and has the \#OrangBaik Movement, \#IndonesiaLawanCorona.

\section{BIBLIOGRAPHY}

Adyani, Rizka Novia, "Pengaruh Social Media Marketing dan Brand Image terhadap Brand Trust serta dampaknya pada Donation Decision pada Crowdfunding Kitabisa.com di era pandemi COVID-19", Thesis submitted for the Program Studi Management Fakultas Ekonomi Universitas Islam Negeri Syarihidayatullah Jakarta, 2012.

Amalia, Nanda, dkk, "Faktor-Faktor Yang Mempengaruhi Milenial Berdonasi Online Melalui Crowdfunding Platfrom: Studi Kitabisa.com", Jurnal Hukum dan Ekonomi Syariah, Vol. 08, No. 2.

Andriani, Dian, "Kampanye Sosial di Media (Studi Kasus Computer Mediated Communication Pada Platfrom Crowdfunding Kitabisa.com)", Thesis submitted for the Fakultas Ilmu Dakwah dan Ilmu Komunikasi Univertas Islam Negeri Syaruf Hidayatullah Jakarta, 2017.

Annisawati, Asaretkha Adjane, "Pengaruh Brand Trust Kitabisa.com Terhadap Niat Berdonasi Secara Online (Studi Kasus: Masyarakat Kota Bandung), Jurnal Bisnis dan Pemasaran, Vol. 10, No.1, 2020. 
Astuti, Windi, Budi Prijanto, "Faktor yang Memengaruhi Minat Muzaki dalam Membayar Zakat Melalui Kitabisa.com: Pendekatan Technology Acceptance Model dan Theory of Planned Behavior", Jurnal Al-Muzara'ah, Vol. 9, No.1, 2021.

Barthelemy, Ferdiza dan Irwansyah, "Strategi Komunikasi Crowdfunding melalui Media Sosial", Jurnal PTEK-KOM, Vol. 21 No. 2, Desember 2019.

Efendi, Mansur, "Pengelolaan Filantropi Islam di Tengah Pandemi Covid-19: Studi Pada Komunitas Kurir Sedekah", Filantropi: Jurnal Manajemen Zakat dan Wakaf , Vol. 2 , No. $1,2021$.

Fauziah, Nurul, "Internet Sebagai Media Fundraising (Studi Deskriptif pada Penggunaan Website Kitabisa.com)", Thesis submitted for the Fakultas Ilmu Sosial Dan Humaniora Unviersitas Islam Negeri Sunan Kalijaga Yogyakarta, 2017.

Hidayanto, Syahrul \& Ishadi Soetopo Kartosapoetro, "Strategi Digital Branding pada Startup Social Crowdfunding (Studi Kasus pada Kitabisa.com)", Jurnal KOMUNIKATIF Vol. 9 No. 1 Juli 2020.

Intyaswati, Driana "Pesan Komunikasi Dalam Penggalangan Dana Melalui Website", Jurnal INFORMASI Kajian Ilmu Komunikasi, Vol. 46. No. 1, 2016.

Munandar, Siswoyo Aris "Gerakan Filantropi Jaringan Gusdurian di Tengah Wabah Covid-19", Jurnal Bimas Islam, Vol. 14, No. 1, 2021.

Situmeang, Muhammad Roby Wafi, "Motif Penggunaan Campaign Dalam Website Kitabisa.com Terhadap Minat Penyadang Dana Berdonasi (Studi Korelasi Penggunaan Campaign dalam Website Kitabisa.com Terhadap Minat Penyandang Dana Berdonasi Pada Kalangan Mahasiswa Ilmu Sosial dan Ilmu Politik Universitas Sumatera Utara)", Thesis submitted for the Fakultas Ilmu Sosial dan Ilmu Politik Universitas Sumetra Utara, 2020.

Tim Kementrian Kesehatan RI, Anaslisis Kebjikan Peran Filantropi Dalam Pembangunan Kesehatan, (Jakarta: Pusat Analisis Determinan Kesehatan Kementrian Kesehatan RI, 2019).

Warapsari, Dhyayi, "Crowdfunding sebagai Bentuk Budaya Partisipatif pada Era Konvergensi Media: Kampanye \#BersamaLawanCorona (Kitabisa.com)”, Jurnal Avant Garde, Vol. 08 No. 01, 2020.

Wibowo, Aulia Satrio, "Perbedaan Perceived Trustworthiness Mahasiswa Pemberi Donasi Pada Penggalang Dana Ditinjau Dari Jenis Online Platfrom yang Digunakan", Thesis submitted for the Universitas Negeri Semarang, 2020. 